\title{
A Study of Malachi 3:8-12 in Relation to Tithing in some Churches in Nigeria
}

\author{
SOLOMON O. ADEMILUKa (UNIVERSITY OF SOUTH AFRICA)
}

\begin{abstract}
In Mal. 3:8-12 the Israelites are accused of robbing God in terms of defaulting in payment of tithes and offerings. This article examined this text and appraised its influence on attitudes to tithing in Nigerian churches, particularly those that make tithe payment compulsory. The essay employs the descriptive and exegetical methods. Contrary to the suggestion of a three-tithe system in the OT by some scholars, the article postulated that each of the $D$ and $P$ accounts on tithing represents $a$ separate tithing tradition at a different time in Israelite history. The tithes demanded of the people in Mal. 3:8-12 are in respect of the Priestly tithing law. The article concluded that Mal. 3:8-12 is not applicable to modern Christians for several reasons. In the OT only farmers who were landowners paid tithes; hence if this text were to be applied today, collecting tithes from other professionals would amount to breaking the law. In contrast to the modern church ministers, the Levites were paid tithes because they were traditionally denied land ownership. Since there are no laws preventing Nigerian pastors from owning land, they are not qualified to receive tithes. Most importantly, the doctrine of compulsory tithing does not find support in the NT.
\end{abstract}

KEYWORDS: Malachi; tithes; Levites; churches; Nigeria

\section{A INTRODUCTION}

In Mal. 3:8-12 the Israelites are accused of robbing God, which is explained as their default in the observance of tithes and offerings. For this disobedience they are under a curse in terms of crop failure possibly arising from drought and devastation by pests. If they pay their tithes and offerings, God will bless them with rainfall and cause the pests to cease so that their crops will yield plentifully. In Nigeria this text influences the attitudes of the churches in various ways. However, in this article the focus is on those denominations that appropriate the passage to teach that tithing is compulsory for Christians. The aim of the article is to study Mal. 3:8-12 with a view to appraising its influence on attitudes to tithing in Nigerian churches with particular reference to those that make tithing compulsory. It employs the descriptive method for the elucidation and appraisal

\footnotetext{
Submitted: 18/01/2019; peer-reviewed: 26/06/2020; accepted: 29/07/2020. Solomon O. Ademiluka "A Study of Malachi 3:8-12 in Relation to Tithing in some Churches in Nigeria," Old Testament Essays 33 no. 2 (2020): 285 - 305. DOI: https://doi.org/10.17159/2312-3621/2020/v33n2a8.
} 
of tithing in Nigerian churches, and the exegetical approach for the study of the passage. The target group is those churches which teach that tithes are compulsory for Christians. To achieve its aim, the article examines how the passage influences attitudes to tithing across the denominations; tithing in the OT; and attitude to tithing in the NT Church. The paper also does an exegesis of the Malachi text and finally examines the implication of the study for the doctrine of compulsory tithing.

\section{B ATTITUDES TO TITHING IN NIGERIA}

In Nigeria tithing is a well-known practice in the church. While there are no churches that reject tithes from their members, attitudes to the doctrine are of two major kinds, namely those who teach that tithing is voluntary and those denominations where it is obligatory. Many of the mainline churches encourage their members to pay tithes but make it voluntary. In the Catholic Church, for instance, "Payment of tithe, like other donations ... is not obligatory. It is purely voluntary." There are also some relatively recent churches that make payment of tithes voluntary. In this category is Daystar Christian Centre, Lagos. The General Overseer, Pastor Sam Adeyemi, states clearly that "tithe, as practiced under the law of Moses, has expired. The death and resurrection of Jesus have put paid to it.... No Christian should feel guilty for not paying tithe."2 Similarly, Pastor Tunde Bakare of Latter Rain Assembly, Lagos, says ... "it is not compulsory for Christians to give $10 \%$ of their income to the church."

While there are a few of the mainline churches that teach compulsory tithing, this teaching is most prominent in the neo-Pentecostal denominations. Among the mainline denominations which teach that Christians should pay tithe is the Anglican Communion. Bishop Bolanle Gbonigi once "stated that paying tithes to the church is biblical, though it doesn't have to be cash." 4 Archbishop Ola Makinde of the Methodist Church Nigeria held the same view when he said that "refusing to pay tithe is robbing God and those that refuse to pay tithes are punishing themselves," apparently relying on the Malachi passage. ${ }^{5}$ Nonetheless,

1 Nureni Lawal, "Is it compulsory or not to Pay Tithes? Abiara, Gbonigi, others Share their Opinions," Naij.com, https://www.legit.ng/1139929-is-compulsory-paytithes-abiara-gbonigi-share-opinions.html.

2 "Daystar Pastor, Sam Adeyemi, Dares other Pastors over Tithing," Thisday 4 March 2018, https://www.thisdaylive.com/index.php/2018/03/04/daystar-pastor-samadeyemi-dares-other-pastors-over-tithing/.

3 Dimeji Akinloye, "Tunde Bakare: 'It's not compulsory to pay tithe, Cleric says,", Pulse 22 February 2018, https://www.pulse.ng/communities/religion/tunde-bakaresays-its-not-compulsory-to-pay-tithe-id8024264.html.

4 Lawal, https://www.legit.ng/1139929-is-compulsory-pay-tithes-abiara-gbonigishare-opinions.html.

5 Lawal, https://www.legit.ng/1139929-is-compulsory-pay-tithes-abiara-gbonigishare-opinions.html. 
the teaching that tithing is obligatory for Christians is most pronounced in the neo-Pentecostal churches, and this teaching is usually supported with Malachi 3:8-12 and "its accompanying pronouncement of woes and curses for noncompliance." In these and most other churches where tithing is practised, every tithe payer is issued a card in which his/her weekly payments are recorded, which payments are in turn recorded in a church ledger for official documentation. ${ }^{7}$ At a point during every Sunday worship service, tithe payers are made to stand up or come to the front while the pastor prays for them to receive God's blessings before the tithes are finally dropped in the tithe box. In some places before the pastor prays he gives a short exhortation to promote tithe payment, the exhortation, which is usually supported with relevant biblical passages, particularly the Malachi text. ${ }^{8}$ The Assemblies of God Church is one of these neo-Pentecostal denominations. It teaches its members that "Tithe is Holy unto the Lord" and should be paid promptly and correctly, as tithe payment also demonstrates members' faithfulness to God. ${ }^{9}$ Members are frequently reminded that their tithes cannot be passed for the Sunday school or church offering; neither can tithes be used as a gift to the pastor or church project levy or any other contribution whatsoever. ${ }^{10}$ Relying on the Malachi text the Assemblies of God Church claims that non-payment of tithes "is direct transgression of the law of God" and therefore portends danger for defaulters. ${ }^{11}$

Nevertheless, the teaching that non-payment of a tithe is a violation of God's law is stricter in Living Faith Church (a.k.a. Winners' Chapel) and the Redeemed Christian Church of God (RCCG). At Winners' Chapel a tithe is defined as "the tenth part of whatever increase a person enjoys.... It does not belong to anyone but to God." "Payment of tithes is compulsory for all members - "ministers, housewives, children, students, and the unemployed."13 The founder of the church, David Oyedepo, is reported as saying that "Tithing is ... the master key to enjoying financial miracles." 14 Defaulting in the payment of a tithe amounts to robbing God, and this cannot be without consequences. As

6 Paul Eri, "The Church, the Tithe, and Daddy Freeze," Sahara Reporters, 17 December 2017, http://saharareporters.com/2017/12/17/church-tithe-and-daddy-freeze -paul-eri.

Habila Kitause Chukwuka Achunike, "A Historical Discourse on Tithing and Seed Sowing in some Nigerian Pentecostal Churches," IOSR Journal of Humanities and Social Science 8/3 (2013), 15.

8 Efe Ehioghae, "Tithing and the Quest for Material Prosperity: A Critical Evaluation of Contemporary Trends in Nigerian Pentecostalism," AAMM 6 (2012), 12.

$9 \quad$ Nwokoro, cited by Kitause and Achunike, "Historical Discourse," 15

10 Nwokoro, cited by Kitause and Achunike, "Historical Discourse," 15

11 Nwokoro, cited by Kitause and Achunike, "Historical Discourse," 15

12 Ehioghae, "Tithing and the Quest for Material Prosperity," 155.

13 Ehioghae, "Tithing and the Quest for Material Prosperity," 12

14 Oyedepo, cited by Ehioghae, "Tithing and the Quest for Material Prosperity," 12 
taught in Malachi 3, defaulters "will be harassed by devourers [in terms of] frequent car breakdowns, losses, sickness and so on." 15 Apparently having Mal 3:10 in mind, Oyedepo claims that God will not open the heavens for Christians who do not pay tithes no matter what they do. ${ }^{16}$ In the RCCG tithe payment is also obligatory, and this is emphasised in all the church's manuals. ${ }^{17}$ Defaulting in payment of tithes is seen as a most grievous sin in this church in that the General Overseer, Pastor Enoch Adeboye, is reputed to have taught that defaulters will not go to heaven. According to him,

Anyone who is not paying his or her tithes fully is not going to Heaven. Some people have taught you that if you do not pay your tithes, God will not give you blessings. This is true, but a little more serious. You do not pay your tithes; you do not go to Heaven ... [because] there are no robbers in Heaven. The Bible calls those who do not pay their tithes robbers in Mal. 3:8. ${ }^{18}$

Thus, these churches teach on the basis of Mal 3:8-12 that tithing is not only compulsory for Christians, but that defaulting amounts to being a serious sin that may even deny one inheritance of God's kingdom. The thrust of this article is to examine this claim in light of the understanding of the Malachi text as presented in its exegesis as undertaken later in the article. But before the exegesis, there is a need to examine the concept of tithing in the OT.

\section{TITHING IN THE OLD TESTAMENT}

The Hebrew noun מעשר, meaning 'tithe' or 'tenth part', is a cognate of the verb עשר , 'to tithe' or 'take the tenth part.' 19 As defined by Tate, "tithing refers to the giving or taking of a tenth of a property, produce or money for some institution or purpose. $" 20$ Just like circumcision, sacrifice, dietary rules, and other customs, in the ancient Near East tithing was not practised only in Israel, as evidence abounds that it was practised among the Egyptians as well as the Mesopotamians. ${ }^{21}$ In the OT the term מעשר occurs first in the story of Abram offering a tithe to Melchizedek (Gen 14:20). It appears also in Gen 28:22 where Jacob vows a tithe to God if God saves him and he returns to his father's house in peace. In the Mosaic law the word appears in Lev. 27, Num. 18, and Deut. 12, 14,26 . Outside the legal corpus the term appears not often in the OT. In the pre-

15 Ehioghae, "Tithing and the Quest for Material Prosperity," 12

16 Lawal, "Is it compulsory or not to Pay Tithes?" https://www.legit.ng/1139929-iscompulsory-pay-tithes-abiara-gbonigi-share-opinions.html.

17 Kitause and Achunike, "Historical Discourse," 13.

18 Adeboye, in by Kitause \& Achunike, "Historical Discourse," 13.

19 Ronald Allen, "מעשר," in TWOT 2:705.

20 Cited by Lekgetho Moretsi, "Tithing: An Evaluation of the Biblical Background," In die Skriflig 43/2 (2009), 400.

21 Allen, TWOT 2:702 
exilic texts after the Torah it occurs only in Amos 4:4, apart from 2 Chr. $31^{22}$ which records tithes in the reform of Hezekiah. In the post-exilic texts מעשר is found six times in Nehemiah and twice in Mal. 3:8-10. In Ezek. 45:11-14 the word is used twice referring to a tenth part of a measurement. ${ }^{23}$ In view of the purpose of this article, in this section the focus is on tithing in the Mosaic law.

The major texts that describe the regulations concerning tithing in the Pentateuch are Lev 27:30-33, Num. 18:21-32 and Deut. 14:22-29. In the Leviticus passage, "All the tithe of the land, whether of the seed of the land or of the fruit of the trees, is the LORD's; it is holy to the LORD" (v.30, RSV). Like the fruits of the land, herds and flocks are also to be tithed. A tithe might be redeemed but the payer would have to add a fifth to it (vv.31-32). In Num. 18, Yahweh sets aside for the Levites "every tithe in Israel for an inheritance, in return for their service ... in the tent of meeting" (v.21, RSV). The Levites in turn are to pay a tenth of what is paid to them "to the LORD, a tithe of the tithe" (v.26, RSV). In Deut. 14:22-27 (cf. 12:5-7), every Israelite family shall tithe all the produce of the land every year, grain, wine, oil, and the firstlings of herds and flocks. All Israelites shall take these tithes to a central place and there have a feast before the Lord. If the central place is too far, the family might convert the tithe to money for easy conveyance, and at the place of the feast buy whatever they choose with the money, such as oxen, or sheep, or wine or strong drink, and consume it in the feast. In this celebration, they shall make provision for the Levites. Deut. 14:28-29 provides that at the end of every third year the Israelites shall pile up all the tithes of that same year within the towns for the support of the Levites (because they have no land inheritance), resident aliens, orphans, and widows.

The usual pattern of approach to these passages among scholars is the attempt to identify the number and categories of tithes offered by the Israelites. Many have identified three types of tithe, namely a tithe to the Lord in Lev 27:3033 which is considered to be the same as the one given to the Levites in Num. 18:21-32, an annual tithe expended in a communal feast (Deut. 14:22-27), and the third-year tithe meant for the support of the poor in 14:28-29 (cf. 26:12). Keathley ${ }^{24}$ points out the possibility of three separate tithes in the Pentateuch. The first tithe is that contained in Leviticus 27 and Numbers 18, a tithe set aside for the Levites. The second tithe was used for celebrations at the central sanctuary (Deut. 14:22-26) while the third one was meant for the local Levites,

22 Apart from the fact that this passage (2 Chr. 31:6-8) does not give any details on tithing, 1 and 2 Chronicles originated in the post-exilic era (Longman \& Dillard, $A n$ Introduction to the Old Testament [Michigan: Zondervan, 2006], 190; cf. 1 Chr. 3:1724; 29:7; 2 Chr. 36:22-23); Therefore, the text cannot appropriately be used to determine tithing practices in the pre-exilic times.

23 Allen, TWOT 2:705

24 Hampton Keathley, "Financial Faithfulness," unlabelled, www.bible.org. 
the foreigners, orphans and widows (14:28-29). Henry Lansdell ${ }^{25}$ agrees with this view, stressing that the tithe mentioned in Lev 27 is the same with that of Num. 18. Jagersma ${ }^{26}$ identifies three different tithes in the OT but differs from Keathley and Lansdell in that he finds a Levitic tithe in Deut. 14:27, which simply states that the Levite should not be forsaken, and equates it with the one in Num. 18. The second tithe is the one eaten by the payer and his family at the central sanctuary (Deut. 14:22-26), while the third tithe is the third-year tithe (Deut. 14:28-29). Morrison seems to share Jagersma's view that Deut. 14:27 is a reference to the Levitic tithe when he states that "the tithe that was shared with the Levites during the festivities could have easily been the Levitic tithe." ${ }^{27}$ Croteau $^{28}$ is in support of the view that Deut. 14:28-29 represents the third type of tithe, the so-called tithe of alms. This tithe is different from the others because it was given every three years, and meant for the Levites, aliens, and other poor people.

From the discussion above it is already apparent that the thesis of a threetithe system poses a number of uncertainties, particularly the relation of the thirdyear tithe to the Levitic and festive tithes. Budiselic points out the problems thus:

[T] he question is whether this tithe, which was given every third year, is an addition to the Levitic and festival tithes [which] ... would mean that the Israelites gave $23.2 \%$ (sic) of their annual income as a tithe. Is the tithe every third year a substitute for the festive tithe and redirected for other purposes (i.e. not the holidays, but for the needy), which would mean that the Israelites gave $20 \%$ of their annual income as tithe? Or was this just another way of using the annual tithe [i.e., the Levitic and festive tithe seen as one] for various purposes? This would mean that the Israelites were giving $10 \%$ of their annual income, which was used for three different purposes. ${ }^{29}$

Croteau opines that the tithe of alms could not have been a substitute for the Levitic tithe because that would mean that the Levites were receiving tithe only once in three years, whereas they had no other means of livelihood. ${ }^{30}$

25 Lansdell, cited in Ervin Budiselić, "The Role and the Place of Tithing in the Context of Christian Giving" Part 1, KAIROS - Evangelical Journal of Theology VIII/2 (2014), 149.

26 Hendrik Jagersma, "The tithes in the Old Testament," in Remembering all the Way: A collection of Old Testament Studies Published, ed. B. Albrektson et al. (Leiden: Brill, 1981), 124.

27 Morrison, cited in Ervin Budiselić, "The Role and the Place of Tithing in the Context of Christian Giving," KAIROS - Evangelical Journal of Theology VIII/2 (2014), 149.

28 David Croteau, "A Biblical and Theological Analysis of Tithing: Toward a Theology of Giving in the New Covenant Era," Dissertation, 2005, 92.

29 Budiselić, "The Role and the Place of Tithing," 149.

30 Croteau, "A Biblical and Theological Analysis of Tithing," 92. 
However, in this observation Croteau seems to lose sight of Deut. 14:27 which some have actually identified as an annual Levitic tithe, as earlier mentioned. The author also states that if the tithe of alms was a substitute for the festive tithe, that would imply that the Israelites neglected certain festivities each third year for no reason. In this regard, Croteau fails to realise that this need not be an issue for the Israelites if it was their custom to vary certain festivals every third year.

Perhaps, in realisation of the problems of the thesis of a three-tithe system, other scholars have suggested a harmonisation of the texts to get a one-tithe system. According to Lemmon, "in the first and second year the tithe was brought to Jerusalem and it was eaten there, while every third year the tithe was brought into the city storehouses and then divided among the Levites, who would then give a tenth of what they received for the priests." ${ }^{31}$ As Budiselic puts it, "During the first, second, fourth and fifth years the tithe was to be brought to Jerusalem, while it would remain stored in Levitic towns during the third and sixth years ... [Thus] the Israelites were giving only $10 \%$ of their income as a tithe." 32 Van der Merwe also supports the view that "A one-tithe-with-differentuses scenario is consistent with the information contained in the various tithing texts [which] confirms the idea that tithing was an annual occurrence that had a variety of applications, but primarily the support of the Levites." 33

There have also been attempts to interpret the tithing texts from the perspective of Julius Wellhausen's ${ }^{34}$ thesis of a gradual development of Israelite religion. Wellhausen had conjectured that in the earliest stages of Israelite religion, people offered sacrifices when and where they liked without any priestly interference. This was the situation until King Josiah intervened at the end of the monarchy, limiting all worship to Jerusalem, thereby giving power to the priests to control the details of worship. The priests consolidated this power, "and during the exile they invented all sorts of rules and regulations about the details of worship [including] ... their entitlement to tithes." ${ }^{35}$ Apparently following Wellhausen's line of thought, some have claimed that the tithing tradition witnessed a gradual evolution. For example, taking Deut. 14:22-29 and 15:19- 23 as his premise, Pryce identifies three stages in the practice of tithing in ancient Israel. The first phase is represented in the festive tithe (Deut. 14:22-

31 Lemmon, cited in Budiselic, "The Role and the Place of Tithing," 149.

32 "The Role and the Place of Tithing," 150.

33 Cited in Jo-Anne van der Merwe, "An exegetical and Theological Study of Malachi 3:8-12 and its Implications for Christians, with Particular Reference to Tithing," Thesis, 32, https://www.sats.edu.za/userfiles/vd\%20Merwe\%20J\%20MTh \%20final\%20thesis\%20Jan2010.pdf .

34 Reported without citation by Gordon Wenham, "The Pentateuch," in New Bible Commentary, ed. Donald A. Carson, et al. (Nottingham: IVP, 1994), 45

35 Gordon Wenham, "The Pentateuch," 45; cf. Longman \& Dillard, An Introduction to the OT, 45 . 
26). The second stage arose when the Israelite society had developed and increasing social problems arose, so much so that each third year the tithe was expended for the need of the Levites and other poor people (Deut. 14:28; 26:12). The third phase came when the number of Levites and the needs of the sanctuary increased so much that a tithe each third year became insufficient; the situation which gave rise to the obligation of an annual tithe to the Levites. ${ }^{36}$

Thus, there are two major views on the practice of tithing in ancient Israel, namely the three-tithe and the one-tithe suggestions. The uncertainties that beset the former suggestion have been highlighted. Another problem with it is that the OT never gives the impression that the Israelites were paying multiple tithes at any given time in their history. Perhaps it is for lack of this evidence that some have attempted to find a single tithing system albeit through a forced harmonisation of the texts. The problem with the thesis of a tithing practice that gradually evolved is that it is too abstract in that it does not back up its claims with proofs. For instance, it does not demonstrate how one stage led to the other; neither does it prove the factors claimed to necessitate the changes.

Perhaps, a most viable approach towards determining the nature of Israelite tithe observance is to go behind the final form of the Pentateuch and recognise each of the $\mathrm{D}$ and $\mathrm{P}$ accounts on tithing as a separate tradition on its own, rather than trying to harmonise them. In other words, each of D and P was most probably a local tithing tradition at a different time in the history of the people of Israel. Davies seems to recognise this fact when he opines that the Deuteronomic and Priestly accounts probably reflect northern and southern (Jerusalem) customs respectively. ${ }^{37}$ This proposition can be clearly demonstrated by a close examination of each of the accounts. Following this approach, the D account (Deut. 14:22-29) need not be seen as presenting two types of tithe but one annual tithe varied in usage, as already suggested by some. The D source is dated in the seventh century, and its origin associated with the reform of Josiah, the focus of which was to centralise Israelite worship in Jerusalem. The need for centralisation arose from the abuse being carried on at the local sanctuaries ( 2 Kgs. 22 \& 23), which seems to agree with Wellhausen's thesis that in the monarchy period worship was characterised by people sacrificing where and when they liked. ${ }^{38}$ This position that worship was not regulated in the monarchy as against the post-exilic period is supported in Amos 4:4 where the prophet criticises the people of northern Israel of transgressing at the local sanctuaries, the transgressions which apparently involved collection of tithes by the priests at such shrines. Hence, it has been plausibly suggested that the D account of tithing

36 Gwilyn Pryce, "The Principle of Giving and the Practice of Tithing," unlabelled, http://www.gwilympryce.co.uk/religious /Tithing\%20Feb \%202000.pdf.

37 Henton Davies, "Deuteronomy" in Peake's Commentary on the Bible, ed. Matthew M. Black \& Harold H. Rowley (Wokingham: Van Nostrand Reinhold, 1982), 277.

38 Wenham, "The Pentateuch," 49. 
is most likely a fairly old custom and probably distinctively northern. ${ }^{39}$ This tithing tradition was most probably not in use in the post-exilic times.

The $\mathrm{P}$ account (Num. 18:21-32), on the other hand, presents a tithing system where the tithe is for the Levites and a tenth of it for the Aaronite priests. As earlier mentioned, Wellhausen had posited that in ancient Israel people offered sacrifices anywhere and anytime they liked until Josiah introduced a regulating priesthood at the end of the seventh century; and that during the exile the priests introduced rules and regulations about the details of worship, including tithing. This proposition is in line with the fact that Josiah's reform was meant to correct the disorderly worship, which means that the apparently organised priestly order represented by $\mathrm{P}$ did not obtain in the pre-exilic era. To further support this view, the Priestly source is traditionally dated in the "fifth or fourth century BCE and related to the exilic/post-exilic era. [Hence] P reflects the post-exilic order of the priesthood." 40 The P, then, represents the tithing practice of the post-exilic community, and unknown in the pre-exilic era. This fact can be further buttressed by its clear closeness to the account in Nehemiah. Similar to the $\mathrm{P}$ account, in Neh. 10:37-39 the people of the restoration community obligate themselves to bring to the Levites the tithes from their produce, and the Levites in turn "shall bring up the tithe of the tithes to the house of our God" (v.38, RSV; cf. Num. 18:26). Commenting on this text, Potkonyak explains that the Levites who received their tithes in their local places would then bring in their tithes to the priests who officiated at the temple. ${ }^{41}$ The connection between the P account and the Nehemiah context is further seen in Neh. 10:34 where the people pledge to bring their tithes in accordance to the law; and when this statement is compared with Num. 18:26, it is clear that the author of Nehemiah most likely had the priestly law in mind. In this way, in anticipation of the interpretation of Malachi 3:8-12, the Nehemiah text reinforces the fact that the people of the post-exilic era considered themselves to be bound by the Law; hence they "obligated to obey its stipulations, with the tithe being an integral part of that Law."

\section{MALACHI 3:8-12 IN RELATION TO TITHING}

The Hebrew word מלאכי (Malachi) literally means 'my messenger,' for which reason some scholars contend that 'Malachi' is not a proper name but an adopted pen name. They claim that the book was originally an anonymous separate collection appended to the book of Zachariah; it was later treated separately in

39 Davies, "Deuteronomy," 277.

40 Longman and Dillard, An Introduction to the OT, 45; cf. Wenham, "The Pentateuch," 49.

41 George Potkonyak, "The Truth of Tithing: A Critical Look at Christian Reconstruction," Theonomy and Dominion Theology, http://members.fortunecity.com/ xena4jesus/id19.htm.

42 Van der Merwe, "An exegetical and Theological Study of Malachi 3:8-12," 48. 
order to have twelve books of the Minor Prophets. However, there are others who believe that 'Malachi' is the name of a prophet about whom we have little information. ${ }^{43}$ Since there is already overwhelming material on this debate, the present article focuses on the interpretation of Mal 3:8-12 in relation to tithing in Nigerian churches. Most scholars fix the historical context of Malachi in the post-exilic era. Some date it specifically between the completion of the second temple in 515 and the careers of Ezra and Nehemiah (456/455 B. C. E.), ${ }^{44}$ which places Malachi before Ezra and Nehemiah. However, some others have plausibly affirmed that Malachi was probably a contemporary of Nehemiah in the midfifth century in view of the implied existence of the temple in 1:10;3:1, 8, which would require a date after its reconstruction in 515 B. C. E. ${ }^{45}$ Relevant for the purpose of this paper, substantial parallels have been identified between the offenses reported by Malachi and those found in Ezra-Nehemiah, including the violation of the tithe law (3:8-10; Neh. 10:32-39; 13:10-13) ${ }^{46}$ In its final form, the book of Malachi contains six disputations, at the heart of which stands the covenant. ${ }^{47}$ Malachi's message is therefore properly recognised as a wake-up call "to renewed covenant fidelity." 48

In Mal. 3:8-12, the Israelites are failing in their covenant with Yahweh in respect to the observance of tithes and offerings, for which reason they are accused of robbing God. If they pay their tithes and offerings faithfully, God will bless them and cause the pests to cease so that their crops will yield bountifully, and other nations will admire them. Scholars have divergent views on the question of the specific tithe being neglected in verse $8 \mathrm{~b}$. Graeme Carlé believes that there is only one tithe in the OT, namely that which was set apart for two purposes in Deut. 14:22-29. The demand to bring the whole tithe to the house of the Lord could refer only "to the tithe which was given every third year for the Levites and the needy." ${ }^{\text {49 }}$ However, as earlier stated, the D tithing tradition was unlikely to be in use in the days of Malachi. Kostenberger and Croteau are in support of the view that Mal 3:8 does not refer to the tithing practice in Deut. 14:22-29. ${ }^{50}$ Although, even when they believe that Malachi 3:6-12 addresses the

43 Longman \& Dillard, Introduction to the OT, 498.

44 Paul Redditt, "The Book of Malachi in its Social Setting," The Catholic Biblical Quarterly 56/2 (1994), 242.

45 Gordon Hugenberger, "Malachi," New Bible Commentary, 883.

46 Hugenberger, "Malachi," in New Bible Commentary, 883.

47 Longman and Dillard, Introduction to the OT, 500; cf. Blessing Boloje and Alphonso Groenewald, "Literary Analysis of Covenant Themes in the Book of Malachi," Old Testament Essays 28/2 (2015), 268-274.

48 Hugenberger, "Malachi," in New Bible Commentary, 884.

49 Cited in Budiselic, "The Role and the Place of Tithing," 155.

50 Andreas Kostenberger and David Croteau, “'Will a man rob God?' (Malachi 3:8): A Study of Tithing in the Old and New Testaments," Bulletin for Biblical Research 16/1 (2006), 70. 
whole of Israel, and not just the priests, these authors hold that the tithe referred to in Mal. 3:8 is only the Levitic tithe since the demand was for the tithe to be brought into the treasury. Kelly similarly claims that Mal 3:8 refers to the Levitic tithe since verse 10 talks about bringing the tithes into the treasury, and that was the only tithe brought into the temple treasury by the Levites upon themselves receiving tithes from the people. ${ }^{51}$ However, the claim that the only tithe brought to the temple was the Levitic tithe cannot be correct because it was out of the tithe that the Levites received from the people that they brought to the temple, which means that part of the tithes paid by the people ended up in the temple. Mal. 3:8-10 is in harmony with this view in that the presentation encompasses both the tithe paid by the people to the Levites and the so-called Levitic tithe. In these verses the people as a nation (v.9) are accused of robbing God in tithes and offerings (v.8), and in verse 10 they are enjoined to bring the full tithes into the storehouse. This presentation also agrees with the demand of the priestly (postexilic) law on tithing. From the relevant texts, this law demands that the people pay their tithes to the Levites, that is, the Levitic tithe (Num. 18:21, 26; cf. Neh. $10: 37,38$ ) annually (cf. Neh. 10:35) in form of farm produce as well as herds and flocks (Lev 27:30,32). The Levites in turn were to pay tithes on the tithes they received to the priests in the temple (Num. 18:26; cf. Neh. 10:38; Mal 3:10). Hence, relying on Lev 18:25-29, Snyman plausibly observes that in Malachi 3:810 the prophet has two groups of tithe payers in mind, that is, the people in general who are admonished to bring their tithes and the priests who are instructed to pay their own tithes from the tithes they received. ${ }^{52}$ Thus, 'the whole tithes' refers to the tithes expected from these two categories of tithe payers. This means that the tithe demanded of the people in Mal. 3 is in respect of the priestly tithe law.

It is important to note that verse 8 puts tithes and offerings together. According to Bowling, the Hebrew word used here for 'offering' is תרומה, meaning 'contribution,' 'offering' or 'heave offering.' In its usages, this term is roughly synonymous with תרופה 'shich is "used both as a general cultic term for various offerings and as a term for those parts of the offerings designated especially for the officiating priest." ${ }^{53}$ In Exodus the term denotes materials contributed for the building of the tabernacle (Exod 25:2-3) and the half-shekel atonement money (30:13). In Num. 15:20 תרופה is used for the offering of a cake from the first of the meal of the land; in 18:26 it refers to the tithe of the tithe designated for the priests whereas in 31:29 it designates the offering of war booty. The sacred precincts of Ezekiel's temple vision (Ezek. 45:1), and

51 Russell Kelly, Should the Church Teach Tithing? (Lincoln: Writers' Club Press, 2007), 48. cf. Van der Merwe, "An exegetical and Theological Study of Malachi 3:8$12, ", 46$.

52 Fanie Snyman, "A Theological Appraisal of the Book of Malachi," Old Testament Essays 27/2 (2014), 604.

53 Andrew Bowling, "תרומה," in TWOT 2: 838. 
contributions of the Persian King and others to rebuild the temple (Ezr. 8:25) are also called תרופה. It may also refer to gifts to idols as in Isa 40:20. ${ }^{54}$ Some suggest that the offerings in view in Malachi 3:8 refer to the portions (such as the guilt offering and the wave offering) reserved for the priests, citing Numbers 18:8-24 as the background. ${ }^{55}$ Feinberg ${ }^{56}$ equates the offerings in Malachi 3:8 with first fruits while Petersen ${ }^{57}$ takes them to be the tithe of the tithes given to support the temple. However, it appears that in this passage the term תרומה is used in the general sense to refer to all items paid as tithes and offerings in the post-exilic era, the list of which can be deduced from Neh. 10:35-38. There the people pledge to bring to the Lord all their contributions, the first fruits of farm produce and the firstlings of herds and flocks; they would also bring their tithes to the Levites who in turn would pay the tithe of the tithes to the Lord. Since Malachi and Nehemiah arose from the same historical context, it can be plausibly suggested that they share the same conception of tithes and offerings.

Taking verses 9-11 together, the people of Israel were under a curse as a consequence of their failure to pay tithes and offerings. Many interpreters agree that the nature of the curse is spelt out in verse 11 in terms of crop failure which in turn was the result of drought and damage by pests. ${ }^{58}$ Keil and Delitzsch take the devourer in verse 11 as a probable reference to locusts "which would devastate crops, leaving barren land in their wake." ${ }^{59}$ Considering the curse in this way can be supported from the book of Haggai, another of the post-exilic books. As in Mal. 3, in the time of Haggai the people apparently suffered severe drought (1:11). They also experienced poor harvests (2:16) as well as devourers in terms of crop diseases like blight and mildew (2:17). As Hugenberger puts it, Yahweh reveals that these natural disasters were the result of the nation's disobedience in bringing their tithes and offerings to the Lord. But if they would bring their full tithes and offerings the Lord would open the windows of heaven for them for an overflowing blessing; he would cause the pests to cease, and Israel would be a land of delight to other nations (vv.10-12) ${ }^{60}$ In view of the similar expressions in passages such as Gen 7:11-12, Deut. 11:14 and

54 Bowling, in TWOT 2: 838.

55 E.g. Ray Clendenen, Haggai Malachi: The New American Commentary: An Exegetical and Theological Exposition of Holy Scripture. Vol. 21 (Nashville, TN: Broadman and Holman Publishers, 2004), 418.

56 Cited in Van der Merwe, "An exegetical and Theological Study," 47.

57 Cited in Van der Merwe, "An exegetical and Theological Study," 47.

58 Lekgetho Moretsi, "An Exegetical Study of Malachi 3:6-12 with Special Reference to Tithing," Dissertation, 2004, 67, http://dspace.nwu.ac.za/bitstream/handle/10394 /1097/moretsi_lekgethoh.pdf;jsessionid=F62F6A0FC7294497BB603070872BDD4E? sequence=1; Snyman, "A Theological Appraisal," 604; Van der Merwe, "An exegetical and Theological Study," 48.

59 Cited in Van der Merwe, "An exegetical and Theological Study,” 52.

60 Hugenberger, "Malachi," New Bible Commentary, 888. 
particularly 28:12, several scholars have accepted the concept of the 'windows of heaven' in verse 10 as a reference to rain. ${ }^{61}$ This means that if the people of Israel would be "faithful in presenting their full tithes, the desperately needed rain will come, pestilence and crop failure will cease, and all nations will call Israel blessed." 62 In Stuart's interpretation of Mal 3:12 God's favour upon Israel would be abundantly evident to other nations, and they would no longer be the subject of scorn and derision. ${ }^{63}$

The last section of this article assesses the attitudes to tithing in Nigeria in light of the understanding of this passage as presented here. However, before then there is a need to examine the influence, if any, of the Malachi passage in the NT Church.

\section{E ATTITUDE TO TITHING IN THE NEW TESTAMENT CHURCH}

There is no evidence of Jesus' direct teaching on the subject of tithing but a few of his sayings indicate that tithing was being practised during his time. The parable of Jesus in Lk 18:9-14 reflects the fact that the Pharisees paid tithes on virtually every possession and considered tithe payment as an act of righteousness. Similarly, it is evident in Mt 23:23 (cf. Lk 11:42) that members of the sect tithed the smallest of their belongings that derived directly from the soil. It shows that they tithed even herbs such as mint, dill and cumin, apparently in obedience to Lev. 27:30. ${ }^{64}$ Allen may therefore be correct when he says that as at the time of Jesus everything edible that derived its nourishment from the soil was liable to be tithed. ${ }^{65}$ Mt. 23:23 contains the fourth of the woes which begin in verse 13 , that Jesus addressed to the Pharisees, indicting them for their show of righteousness while in reality they were hypocritical and lawless (v. 28). Verse 23 criticises them for "obscuring the true intent of the law in their meticulous attention to paying tithes on everything, while leaving the fundamentals of justice, mercy and faithfulness undone." 66 At the end of the verse, Jesus remarks, "these you ought to have done without neglecting the others" (RSV). In view of this statement Mt. 23:23 is sometimes cited as evidence that tithing is an NT practice apparently endorsed by Jesus himself, and therefore a duty that still applies to Christians today. ${ }^{67}$ However, there are problems with that line of thought. Carson is correct when he observes that this

61 Cf. Van der Merwe, "An exegetical and Theological Study," 51.

62 Hugenberger, "Malachi," New Bible Commentary, 888.

63 Douglas Stuart, The Minor Prophets: An Exegetical and Expository Commentary. Vol. 13 (Grand Rapids, MI: Baker Books, 1998), 1370.

64 Donald Hagner, Word Biblical Commentary: Matthew 14-28 (Texas: Word Books, 1995), 670.

65 Willougby Allen, International Critical Commentary on the Gospel According to St. Matthew (Edinburgh: T \& T Clark, 1972), 247.

66 Van der Merwe, "An exegetical and Theological Study," 55.

67 Van der Merwe, "An exegetical and Theological Study," 55. 
text is not a commentary on the requirements of the New Covenant that was yet to be inaugurated. ${ }^{68}$ On the contrary,

Jesus is [here] dealing with the Pharisees on the basis of the Law that they, as observant Jewish leaders, were required to follow; the New Covenant had not yet been instituted. [Moreover,] it should be noted that the main thrust of Matthew 23:23-34 is not tithing, but the "weightier" aspects of the Law. To focus on the Pharisees' scrupulous tithing is to miss the larger issue, which is just what the Pharisees themselves were doing. ${ }^{69}$

It is also important to take note of the items mentioned as tithed in $\mathrm{Mt}$ 23:23, all of which are not certain to be covered under the OT tithing law, ${ }^{70}$ which means that the Pharisees actually went beyond the law in including those items. ${ }^{71}$ As Van der Merwe plausibly suggests, if this passage is accepted as Jesus' endorsement of tithing, there arises the problem of how to determine what items are subject to be tithed. ${ }^{72}$ Mt 23:23, therefore, cannot be used to support the argument that Christians should pay tithes.

Another text that mentions tithe in the NT is Heb. 7:1-10, the passage which retells the story of Abram's encounter with Melchizedek after the former's defeat of some kings in the region (Gen 14). As with Mt 23:23 this text is sometimes quoted as evidence that the New Covenant sanctions tithing for Christians. For example, Pink posits that Abraham is a type just as Melchizedek is a type; if Abraham who is the father of the faithful paid tithes, Christian believers, being his children, should also pay tithes. ${ }^{73}$ Relying on the Hebrews passage, Taylor ${ }^{74}$ also states that tithing did not originate with Moses, and so he cannot end it. Moretsi similarly believes that Heb. 7:1-10 treats tithing as an ongoing practice many years after the death of Jesus. ${ }^{75}$ It is important to note, however, that the concern of Heb. 7:1-10 is not the payment of tithe but that of the Messianic Priest who would arise after the likeness of Melchizedek. ${ }^{76}$ That Abraham paid tithe to Melchizedek and the latter blessed him implies that Melchizedek was superior to Abraham; that is why the priesthood of the Son

68 Donald Carson, Matthew, Mark, Luke: The Expositor's Bible commentary. 8 vols. (Grand Rapids, MI: Zondervan, 1984), 481.

69 Carson, cited in Van der Merwe, "An exegetical and Theological Study," 55.

70 Craig Keener, A commentary on the Gospel of Matthew (Grand Rapids, MI: Wm. B. Eerdmans, 1999), 549.

71 Verbrugge, cited in Van der Merwe, "An exegetical and Theological Study," 56.

72 "An exegetical and Theological Study," 56.

73 Arthur Pink, "Tithing" unlabelled, www.pbministries.org.

74 Al Taylor, Proving God: Triumphant Living through Tithing (Cleveland, TN: Pathway Press, 1991), 76.

75 Moretsi, “An Exegetical Study of Malachi 3:6-12," 88.

76 Van der Merwe, "An exegetical and Theological Study,"58. 
takes after that of Melchizedek and not after that of Levi, Abraham's descendant. This means that the Levitical priesthood would not meet God's purpose of redemption, hence the need for that of the Son (v.11). Therefore, like Mt 23:23, this passage is not relevant in the argument on tithing in the NT. Furthermore, the suggestion that the Hebrews passage indicates that tithing predated the Mosaic law and does not have to end with it cannot be supported from the bible. This is because, as Verbrugge ${ }^{77}$ plausibly points out, there are several other practices (e.g. circumcision) that originated outside of the Mosaic legislation, and yet they are no longer a requirement under the New Covenant. Moreover, since Abraham's payment of tithe to Melchizedek was voluntary, not prior to any command or an obligation to tithe, if it is to be applied today as an argument for tithing it would mean that tithing is not obligatory for Christians.

Furthermore, although some scholars would insist that "the preponderance of Biblical evidence" is in support of the fact that the NT is on the side of tithing, ${ }^{78}$ the practice is conspicuously absent in all the NT texts regarding giving (cf. Rom. 15:25-28; 1 Cor. 9:6-18; 16:1-3; 2 Cor. 8-9; Eph. 4:28). ${ }^{79}$ In the NT the overriding principle concerning Christian giving is summed up in 2 Cor. 8:2-3, namely that it should be voluntary and according to individual ability. ${ }^{80}$ The significance of this conclusion for this study is that the OT concept of tithing as reflected in Mal. 3:8-12 does not have support in the NT.

It is therefore no surprise that there was no tithing in the early church until "the church expanded and its material needs grew more numerous and complex [and] it became necessary to adopt a definite rule to which people could be held either by a sense of moral obligation or by a precept of a positive law;" 81 for which the church found a model in the OT tithing law. Nwokoro ${ }^{82}$ explains that after the apostolic era it became difficult to maintain the church and the early church fathers had to revive the OT tithing system as a means of financing it. By the fourth century the church began to teach payment of tithe on all the produce of the land as a Christian duty. There is evidence that by the sixth century many Christians were paying tithes on their income to the church. ${ }^{83}$ The first church council of 567 in Toars exhorted payment of tithes, ${ }^{84}$ while at the council of Macon in 585 payment of tithes had become obligatory so much that

77 Cited in Van der Merwe, "An exegetical and Theological Study,"58.

78 Sprague, cited in Moretsi, "An Exegetical Study of Malachi 3:6-12,” 89.

79 Moretsi, "Tithing: An Evaluation," 405.

80 Craig Blomberg, I Corinthians: NIV Application Commentary (Grand Rapids:

Zondervan, 1994), 191.

81 Whalen, cited in Moretsi, “An Exegetical Study of Malachi 3:6-12,” 29.

82 Cited in Kitause and Achunike, "Historical Discourse," 10.

83 Cross, cited in Moretsi, "An Exegetical Study of Malachi 3:6-12," 29.

84 Preece, cited in Moretsi, “An Exegetical Study of Malachi 3:6-12,” 29; Nwokoro in Kitause and Achunike, "Historical Discourse," 10. 
excommunication was the penalty for refusal to pay ${ }^{85}$ In 785 Charlemagne (747814) promulgated a decree and signed the compulsory payment of tithes into civil law. ${ }^{86}$ By the subsequent declaration at the Council of Trent tithe defaulters must make restitution fully before they could be reabsorbed into the church. ${ }^{87}$ Imposition of tithes continued until the Reformation ${ }^{88}$ but since then the Catholic Church appears to have stopped the practice of compulsory tithing while the protestant churches have continued generally to observe it. ${ }^{89}$

Thus, compulsory tithing as being practised today in Christendom, for example in Nigeria, arose not in obedience to scripture but as a means of raising money to fund the church, which the early church fathers employed in defiance to the NT teaching on giving. The remaining part of this article examines the implications of the study for the doctrine of compulsory tithing in some Nigerian churches.

\section{F IMPLICATIONS FOR THE DOCTRINE OF COMPULSORY TITHING IN SOME CHURCHES IN NIGERIA}

The first section of this article indicated that on the basis of Mal 3:8-12 a number of churches in Nigeria make payment of tithes compulsory for their members. Others, like Winners' Chapel and the RCCG, go a little further by teaching that non-payment of tithes amounts to a serious sin, the consequence of which manifests in various forms of misfortunes in the lives of defaulters. As seen in that section, the RCCG General Overseer teaches that defaulters will not make heaven. In the first place, the claim that failing to give the tithe brings a curse upon a Christian cannot be reconciled with the NT teaching that Christ has delivered him/her from the curse of the Law. ${ }^{90}$ In Gal 3 Paul makes it clear that the OT laws "have been taken up in Christ" and are therefore no longer applicable to Christians. ${ }^{91}$ In relation to tithing, its connection to the temple and the OT sacrificial system makes the replacement by the Jesus event very significant because that specific system gave way to the New Covenant at Christ's death.$^{92}$ It must be in recognition of this fact that there is no support for tithing in the NT.

There are several other factors that make tithing as indicated in the OT and Malachi impracticable for contemporary Christians. In the first place, Malachi's audience clearly understood the demand of the law in terms of what

\footnotetext{
85 Whalen, in Moretsi, “An Exegetical Study,” 29.

86 Nwokoro in Kitause and Achunike, "Historical Discourse," 10.

87 Nwokoro in Kitause and Achunike, "Historical Discourse," 10.

88 Moretsi, “An Exegetical Study of Malachi 3:6-12," 29.

89 Kitause and Achunike, "Historical Discourse," 10.

90 Budiselic, "The Role and the Place of Tithing," 146.

91 Van der Merwe, "An exegetical and Theological Study," 78.

92 Van der Merwe, "An exegetical and Theological Study," 81, 83; cf. Mt 27:51; Heb. 
should be paid as tithe and how it should be paid, which certainly does not correspond exactly to contemporary realities. In terms of the percentage of income "it is hard to determine a specific numerator for giving a tithe which would be in line with clear biblical instructions." "93 For example, as discussed earlier, in Nigeria as in many other parts of Christendom, the contemporary understanding of tithing is simply giving $10 \%$ of one's monthly income which does not correspond to the biblical standard of annual tithing, and thus not a correct fulfilment of the tithing law. ${ }^{94}$ Perhaps, the difficulty lies more in what is to be tithed. In the OT tithing was based on the increase of the crops and livestock, "which means that the artists, fishermen, and merchants were not obligated to give a tithe at the time.... Furthermore, the priests, the poor people (who had neither land nor livestock), and even those who lived outside of Palestine were exempt from tithing." 95 To this end, if tithing were to be practised today in obedience to the law, it would be applicable only to farmers who are landowners, excluding all other professionals and the unemployed, as against the practice in Winners' Chapel, for instance, where all are made to pay tithes irrespective of economic status. For this reason, as Pryce rightly observes, "Blindly applying the tithe as prescribed by the Law is a weak basis for tithing for modern Christians." 96 Another problem resides in finding correspondence between the OT Levites and contemporary realities. The modern pastor would not simply pass as a Levite because "the Levites formed one part of an entire religious and national system that does not easily transfer to the Christian church." 97 The Levites were paid tithes not only because they worked in the temple but also because they had no land at all, unlike modern pastors who in most cases have land and other forms of property. ${ }^{98}$ In Nigeria, there are no known laws that prevent anyone from owning land or any property for that matter in order to be a pastor, which means that Nigerian pastors would not qualify to receive tithes under the OT tithing law. The NT seems to recognise this lack of correspondence between the OT tithing law and the New Covenant, for which reason it makes provision for church ministers to be supported by the church, but not in terms of receiving tithes (1 Cor 9:6-15). This NT provision is another point supporting the fact that "the Old Testament tithe regulations are not binding for New Testament Christians." 99 This position is aptly supported by Van der Merwe when he brings out the reasons why the OT tithing law cannot be applied to the modern Christian. According to him,

\footnotetext{
93 Budiselic, "The Role and the Place of Tithing," 158.

94 Budiselic, "The Role and the Place of Tithing," 151.

95 Budiselic, "The Role and the Place of Tithing," 151.

96 Pryce, cited in Budiselic, "The Role and the Place of Tithing," 159.

97 Van der Merwe, "An exegetical and Theological Study," 33.

98 Budiselić, "The Role and the Place of Tithing," 146.

99 "The Role and the Place of Tithing," 146; cf. Van der Merwe, "An exegetical and Theological Study," 92.
} 
The difficulties are theological as well as practical. Theological in that there is a sound case to be made against placing Christians under obligation to the Mosaic Law, particularly those laws linked to the sacrificial system. Practical in that the tithe was restricted to agricultural produce, [and] there were limitations as to its beneficiaries... These issues limit the ways in which the texts can be applied to a modern Christian context. ${ }^{100}$

Budiselić similarly concludes that:

The literal application of the tithe as described in the Old Testament is impossible for New Testament believers today... [A]s far as giving a tenth of one's financial income based on the Old Testament practice of tithing is concerned, this can be a good and blessed practice, and only one of the ways in which Christians today can practice giving, but it is not an exclusive commandment. ${ }^{101}$

In other words, Christians are free to give any percentage of their income to support the church, but not as a duty in obedience to the OT tithing law.

\section{G CONCLUSION}

In Mal. 3:8-12 the Israelites are accused of robbing God in terms of defaulting in payment of tithes and offerings, for which reason they are under a curse. On the basis of this text, some churches in Nigeria teach that tithing is compulsory for Christians, and that non-payment of tithes brings misfortunes to defaulters. This article found that as against the three-tithe system in the OT suggested by some scholars, each of the $\mathrm{D}$ and $\mathrm{P}$ accounts on tithing represents a separate tithing tradition at a different time in the history of Israel. The Deuteronomic (D) account is the system in place in the pre-exilic era in the Northern Kingdom, and was most probably unknown in the post-exilic times. The Priestly account in Leviticus and Numbers represents the tithing practice of the post-exilic community, and was most likely unknown in the pre-exilic era. The tithes demanded of the people in Mal. 3:8-12 are in respect of the Priestly tithing law. The article concluded that this text is not applicable to the modern Christian for several reasons. Firstly, there is difficulty in identifying the items of tithing. In the OT, tithing was only on the produce of the land and livestock. The implication for today is that only farmers who are landowners are liable to pay tithes; collecting tithes from other professionals would amount to breaking the law. Another problem has to do with identifying in the contemporary Christian church the group that would correspond exactly to the OT Levites. In contrast to the modern church ministers, the Levites were traditionally denied land ownership because their work was to take charge of the temple, for which reason

100 Van der Merwe, “An exegetical and Theological Study,” 83.

101 Budiselić, "The Role and the Place of Tithing," 146, 160. 
they were paid tithes. This aspect of the tithing law makes it inapplicable in modern times because in Nigeria, for instance, there are no laws that prevent pastors from owning land or any property. This implies that modern ministers are not qualified to receive tithes. Most importantly, compulsory tithing and, worse still, the teaching that defaulting in tithing brings curses upon Christians does not find support in the NT.

\section{BIBLIOGRAPHY}

Adeboye, Enoch A. Behold He Cometh. Lagos: Christ the Redeemer's Ministries, 2003. Ajah, Miracle. "Theological Perspectives on Tithing in the Old Testament and their Implications for Believing Communities in Africa." Thesis for the Degree of Doctor of Theology in Old Testament at the University of Stellenbosch, 2006, 280 pages.

Akinloye, Dimeji. "Tunde Bakare: 'It's not compulsory to pay tithe, Cleric says." Pulse 22 February 2018, https://www.pulse.ng/communities/religion/tunde-bakaresays-its-not-compulsory-to-pay-tithe-id8024264.html.

Allen, Willougby C. International Critical Commentary on the Gospel According to St. Matthew. Edinburgh: T \& T Clark, 1972.

Anon. "Daystar Pastor, Sam Adeyemi, Dares other Pastors over Tithing." Thisday 4 March 2018. https://www.thisdaylive.com/index.php/2018/03/04/daystar-pastorsam-adeyemi-dares-other-pastors-over-tithing/.

Blomberg, Craig. I Corinthians: NIV Application Commentary. Grand Rapids: Zondervan, 1994.

Boloje, Blessing $\mathrm{O}$ and Groenewald, Alphonso. "Literary Analysis of Covenant Themes in the Book of Malachi." Old Testament Essays 28/2 (2015): 257-282. https://doi.org/10.17159/2312-3621/2015/v28n2a4.

Budiselić, Ervin. "The Role and the Place of Tithing in the Context of Christian Giving." Part 1. KAIROS - Evangelical Journal of Theology VIII/2 (2014): 143-162.

Carlé, Graeme. Eating Sacred Cows. Wellington: Emmaus Road Publishing, 2000.

Carson, Donald A. Matthew, Mark, Luke: The Expositor's Bible commentary. 8 vols. Grand Rapids, MI: Zondervan, 1984.

Carpenter, E. Edwin. "Tithe." Pages 861-864 in The International Standard Bible Encyclopaedia. 4 vols. Q-Z. Edited by G. W. Bromiley. Grand Rapids: Eerdmans, 1988.

Cross, F. Leslie. 1957. The Oxford Dictionary of the Christian Church. Oxford: Oxford University Press, 1957.

Clendenen, E. Ray. Haggai Malachi: The New American Commentary: An Exegetical and Theological Exposition of Holy Scripture. 21 vols. Nashville, TN: Broadman and Holman Publishers, 2004.

Croteau, David A. "A Biblical and Theological Analysis of Tithing: Toward a Theology of Giving in the New Covenant Era." Dissertation, Southeastern Baptist Theological Seminary, Wake Forest, 2005.

Davies, Henton G. "Deuteronomy." Pages 269-284 in Peake's Commentary on the Bible. Edited by Matthew M. Black and Harold H. Rowley. Wokingham: Van Nostrand Reinhold, 1982. 
Eri, Paul. "The Church, the Tithe, and Daddy Freeze." Sahara Reporters. 17 December 2017, http://saharareporters.com/2017/12/17/church-tithe-and-daddy-freezepaul-eri.

Ehioghae, Efe M. "Tithing and the Quest for Material Prosperity: A Critical Evaluation of Contemporary Trends in Nigerian Pentecostalism." AAMM 6 (2012): 143-159.

Feinberg, Charles L. The Minor Prophets. Chicago, IL: Moody Press, 1990.

Hagner, Donald A. Word Biblical Commentary: Matthew 14-28. Texas: Word Books, 1995.

Harris, R. Laird, Gleason L. Archer, Jr., and Bruce K. Waltke, eds. Theological Wordbook of the Old Testament. 2 vols. Chicago: Moody Publisher, 1980.

Hugenberger, Gordon P. "Malachi." Pages 883-889 in New Bible Commentary. Edited by Donald. A. Carson, Gordon J. Wenham, J. Alec Motyer, and Richard T. France. Nottingham: IVP, 1994.

Jagersma, Hendrik. "The tithes in the Old Testament." Pages 116-128 in Remembering all the Way: A collection of Old Testament Studies Published. Edited by B. Albrektson et al. Leiden: Brill, 1981.

Keathley, J. Hampton. "Financial Faithfulness." Unlabelled. Online: www.bible.org.

Keener, Craig S. A commentary on the Gospel of Matthew. Grand Rapids, MI: Wm. B. Eerdmans, 1999.

Keil, Carl F. and Delitzsch, Franz. Commentary on the Old Testament. 4 vols. Peabody, MA: Hendrickson Publishers, 2002.

Kelly, Russell. Should the Church Teach Tithing? Lincoln: Writers' Club Press, 2007.

Kitause, R. Habila and Achunike, H. Chukwuka. "A Historical Discourse on Tithing and Seed Sowing in some Nigerian Pentecostal Churches." IOSR Journal of Humanities and Social Science 8/3 (2013):7-19. https://doi.org/10.9790/08371830719.

Kostenberger, Andreas J. and Croteau, David A. “'Will a man rob God?' (Malachi 3:8): A Study of Tithing in the Old and New Testaments." Bulletin for Biblical Research 16/1 (2006): 53-77.

Lawal, Nureni, "Is it compulsory or not to Pay Tithes? Abiara, Gbonigi, others Share their Opinions." Naij.com, https://www.legit.ng/1139929-is-compulsory-paytithes-abiara-gbonigi-share-opinions.html.

Lansdell, Henry. Studies in Tithe Giving Ancient and Modern. London: Society for Promoting Christian Knowledge, 1906.

Lemmon, John. "The Implications of Tithing in the New Testament Christian Church." The Free Gift from God, http://www.freegiftfromgod.com/Tch/TchMain.html.

Longman, Tremper and Raymond B. Dillard. An Introduction to the Old Testament. Michigan: Zondervan, 2006.

McConville, Gordon. "Deuteronomy." Pages 198-232 in New Bible Commentary. Edited by Donald. A. Carson, Gordon J. Wenham, J. Alec Motyer, and Richard T. France. Nottingham: IVP, 1994.

Moretsi, Lekgetho H. "An Exegetical Study of Malachi 3:6-12 with Special Reference to Tithing." A Dissertation Submitted in Partial Fulfillment of Requirements for MTH Degree at North West University, Potchefstroom Campus, 2004. 115 pages. . "Tithing: An Evaluation of the Biblical Background." In die Skriflig 43/2 (2009):397-411. https://doi.org/10.4102/ids.v43i2.229.

Morrison, Michael. Sabbath, Circumcision, and Tithing. Lincoln: Writers' Club Press, 2002. 
Nelson, Art. "The Principle of the Tithe." Lifestream Teaching Ministries, http://www.lifestreamteaching.com/Teaching\%20pdf/Principle\%20of\%20the $\% 2$ 0Tithe.pdf.

Nwokoro, I. N. Tithe: The History and Benefits. Lokoja: Chriso Printers, 2007.

Oyedepo, David O. Pillars of Destiny. Lagos: Dominion Publishing House, 2008.

Petersen, David L. 1995. Zechariah 9-14 and Malachi: Old Testament Library. Louisville, KY: Westminster John Knox Press, 1995.

Pink, Arthur W. "Tithing." Unlabeled, www.pbministries.org.

Potkonyak, George. "The Truth of Tithing: A Critical Look at Christian Reconstruction." Theonomy and Dominion Theology. Online: http://members.fortunecity.com/xena4jesus/id19.htm.

Preece, W. E. Encyclopaedia Britannica. Vol. 22. Chicago: William Bento Publishers, 1971.

Pryce, Gwilym. "The Principle of Giving and the Practice of Tithing." Unlabelled, http://www.gwilympryce.co.uk/religious /Tithing\%20Feb \%202000.pdf.

Redditt, Paul L. "The Book of Malachi in its Social Setting." The Catholic Biblical Quarterly 56/2 (1994): 240-255.

. Haggai, Zechariah, Malachi: The New Century Bible Commentary. Grand Rapids, MI: Wm. B. Eerdmans, 1995.

Snyman, Fanie. "A Theological Appraisal of the Book of Malachi." Old Testament Essays 27/2 (2014): 597-611.

Sprague, Randall. The Money in the Mantle: The Economic Alliance of Prophets, Priest and Kings. Pretoria: Kairos Publishing, 2002.

Stuart, Douglas. The Minor Prophets: An Exegetical and Expository Commentary. 13 vols. Grand Rapids, MI: Baker Books, 1998.

Tate, M.E. “Tithing: Legalism or Benchmark?" Review and Expositor 70/2 (2073):153161. https://doi.org/10.1177/003463737307000203.

Taylor, Al. Proving God: Triumphant Living through Tithing. Cleveland, TN: Pathway Press, 1991.

Van der Merwe, Jo-Anne I. "An exegetical and Theological Study of Malachi 3:8-12 and its Implications for Christians, with Particular Reference to Tithing." MTh Dissertation, South African Theological Seminary, January 2010. 129 pages. Online: $\quad$ https://www.sats.edu.za/userfiles/vd\%20Merwe\%20J\%20MTh \%20final\%20thesis\%20Jan2010.pdf.

Verbrugge, Verlyn D. (ed.). The NIV Theological Dictionary of New Testament Words. Grand Rapids, MI: Zondervan, 2000.

Wenham, Gordon J. “The Pentateuch." Pages 43-53 in New Bible Commentary. Edited by Donald. A. Carson, Gordon J. Wenham, J. Alec Motyer, and Richard T. France. Nottingham: IVP, 1994.

Whalen, J. P. New Catholic Encyclopedia. 14 vols. New York: McGraw-Hill Books, 1967.

Solomon Olusola Ademiluka, Dept of Biblical and Ancient Studies, University of South Africa, Pretoria. ORCID: https://orcid.org/0000-0001-9390-2510. 